\title{
First report of the planktonic copepod Oithona davisae in the northern Wadden Sea (North Sea): Evidence for recent invasion?
}

\author{
Astrid Cornils • Britta Wend-Heckmann
}

Received: 24 October 2014/Revised: 8 January 2015/Accepted: 20 January 2015/Published online: 4 February 2015

(C) Springer-Verlag Berlin Heidelberg and AWI 2015

\begin{abstract}
In October 2010, specimens of Oithona were taken from the List Tidal Basin in the northern Wadden Sea (North Sea) for a biogeographic study on Oithona similis. These specimens could not be assigned to $O$. similis or any of the other Oithona species known from the North Sea genetically. These specimens were identified as Oithona davisae Ferrari and Orsi 1984, a Northwest Pacific species, known as an invasive species from the Black Sea and the northwestern Mediterranean Sea. Recent sampling provided evidence that $O$. davisae is still present in the northern Wadden Sea and may thus now be a permanent plankton species.
\end{abstract}

Keywords Oithona davisae · Non-indigenous species · Copepoda $\cdot$ North Sea $\cdot$ Wadden Sea

\section{Introduction}

In the North Sea, four species of Oithona are found regularly (Razouls et al. 2014): Oithona similis Claus, 1866, Oithona nana Giesbrecht, 1892, Oithona plumifera Baird, 1843, and Oithona atlantica Farran, 1908. Among these species, $O$. similis is the most common species in the North Sea (reviewed in Fransz et al. 1991), which is also true for the northern Wadden Sea (Martens 1980) where it occurs mainly in autumn. O. nana is found also in the Wadden Sea but only in low numbers (Fransz 1983).

Communicated by H.-D. Franke.

A. Cornils $(\bowtie) \cdot$ B. Wend-Heckmann

Alfred-Wegener-Institut, Helmholtz-Zentrum für Polar- und

Meeresforschung, 27570 Bremerhaven, Germany

e-mail: astrid.cornils@awi.de
$O$. plumifera and $O$. atlantica are considered Atlantic species that can be found in the northern North Sea, drifted with a branch of the North-East Atlantic Current (Fransz et al. 1991). The authors also state that "several less common species are typical indicators for temperateoceanic waters", but no species names are provided. Thus, only $O$. similis and $O$. nana would be expected in Wadden Sea samples.

In the North Sea, six alien zooplankton species have been found opposed to 83 zoobenthic species (review in Gollasch et al. 2009). Within the six species, only two copepods were recognised: the calanoids Acartia tonsa and Eurytemora americana. Apart from these records, two other calanoid copepods have been identified from the southwestern North Sea: Acartia omorii (Seuront 2005) and Pseudodiaptomus marinus (Brylinski et al. 2012, Jha et al. 2013). It is assumed that the introduction of these species is most likely related to ballast water discharge (e.g. Gollasch et al. 2009; Brylinski et al. 2012).

During the cause of a biogeography study on $O$. similis, we encountered a small $(<1 \mathrm{~mm})$ species of Oithona in the northern Wadden Sea that could not be identified as any of the known species from the North Sea. Here we describe the characteristics of this species, compare them with those of other Oithona species, and identify the species with notes to its distribution. Possible causes for its introduction to the North Sea are also discussed.

\section{Materials and methods}

The List Tidal Basin is a semi-enclosed bight in the northern German Wadden Sea, surrounded by the islands Sylt and Røm $\varnothing$ and connected with the North Sea only by a tidal inlet (Fig. 1a). It is the location of a zooplankton time 

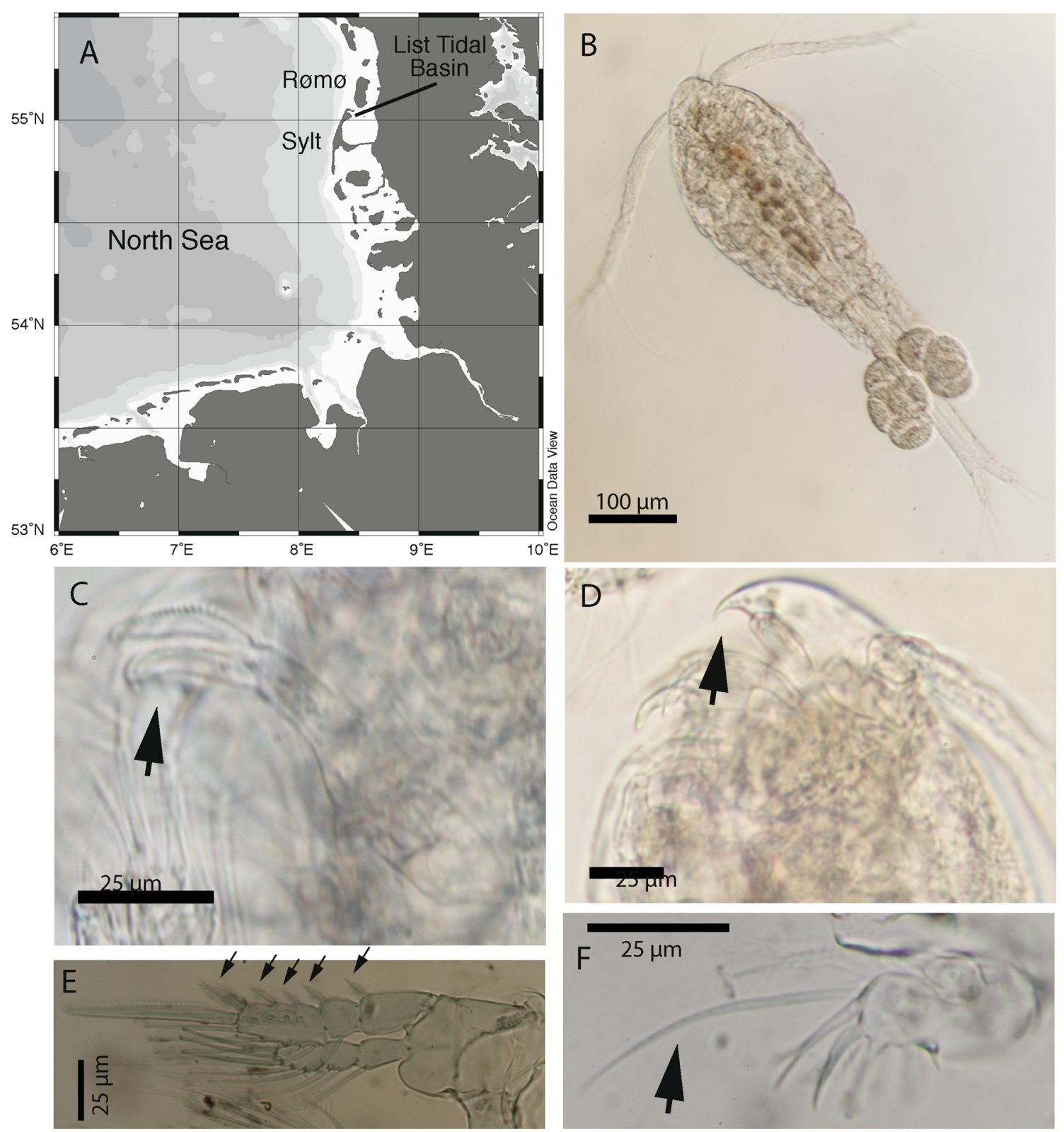

Fig. 1 Map of the sampling location (a) and photographs of $O$. davisae from the Wadden Sea. b Female, habitus, c mandible with terminal setae (arrow), d rostrum (arrow), e swimming leg 3 (arrows

series $\left(55^{\circ} 01.30^{\prime} \mathrm{N}, 08^{\circ} 27.10^{\prime} \mathrm{E}\right.$; Martens and Beusekom 2008). At this station, plankton samples (Apstein net, $80 \mu \mathrm{m}$ mesh size) were taken in October 2010 and $6 \mathrm{Au}-$ gust 2014. Oithona specimens were preserved in $96 \%$ ethanol to allow also molecular analyses.

Total length (measured dorsally) and prosome:urosome ratio of 20 females were measured under a stereo microscope (Leica MZ 16). The length of the prosome was measured from the tip of the forehead to the end of the thoracic segment 4 (Th4); the urosome length included Th5 and the urosome segments to the end of the caudal rami. indicate the outer spines of the exopod), $\mathbf{f}$ maxillule inner lobe 1 (arrow points at long distal seta)

For a detailed inspection of morphological characters, ten female specimens were soaked in Lactic acid and stained with chlorazol black. Subsequently, the specimens were dissected to obtain mouthparts and swimming legs. Specimens were identified according to an identification guide for Oithona (Nishida 1985), the original description of O. davisae (Ferrari and Orsi 1984), and a description of O. zdavisae from the Black Sea (Temnykh and Nishida 2012). DNA of the Oithona species occurring in the North Sea was extracted using the QIAGEN DNeasy Mini kit. The marker gene large-subunit (28S) rRNA was amplified 
and sequenced using the primer set 28SF1 and 28SR1 (Ortman 2008; Cepeda et al. 2012). This gene has been successfully applied to differentiate between Oithona species (Cepeda et al. 2012). Mitochondrial cytochrome c oxidase subunit I (COI) was sequenced using the primer pair LCO1394 and HCO2198 (Folmer et al. 1994) to obtain DNA barcodes for this species to compare with future sequences of $O$. davisae from other regions. PCR amplifications and sequencing were performed according to the protocols of Cepeda et al. (2012) and Wend-Heckmann (2013). In CodonCode Aligner Vers. 3.7.1.1 (CodonCode Corporation), both strands of $28 \mathrm{~S}$ were assembled into consensus sequences and checked for sequencing errors. They were aligned with MAFFT v7.157b under the L-INSI option (Katoh and Standley 2013). New sequences of $28 \mathrm{~S}$ and COI were deposited in GenBank (KP033160KP033188). To enlighten the position of $O$. davisae in comparison with the other Oithona species from the North Sea and from GenBank (for accession numbers see Fig. 2),

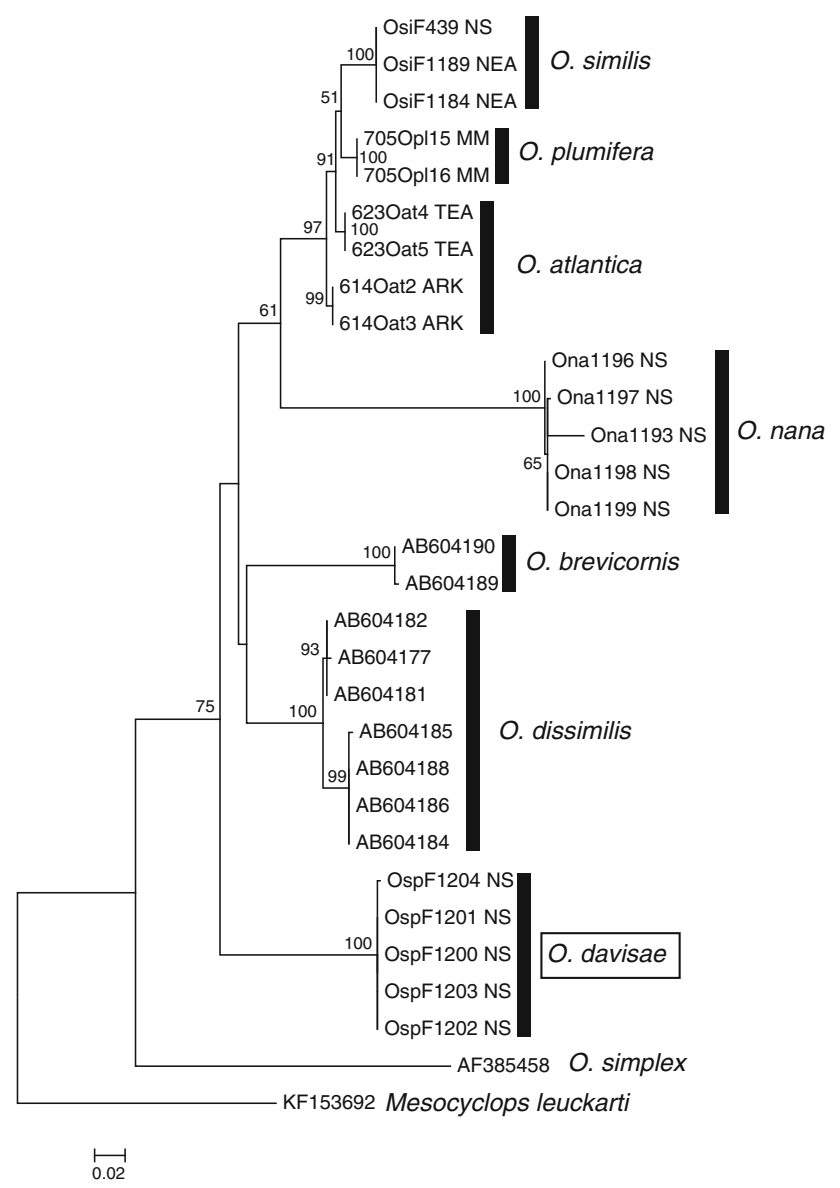

Fig. 2 28S maximum likelihood tree for the North Sea species $O$. similis, O. plumifera, O. atlantica, O. nana, and O. davisae (NS North Sea, TEA Tropical Eastern Atlantic, NEA Northeastern Atlantic, ARK Arctic Ocean) and other Oithona species (taken from GenBank with their accession numbers) a maximum likelihood phylogenetic analysis of $28 \mathrm{~S}$ was carried out with RAxML 7.2.8 (Stamatakis 2006). RAxML was run under the option GTRGAMMA and a complete random starting tree of 10,000 bootstrap replicates. Bestknown likelihood tree search was performed under GTRMIX and a completely random starting tree. The final tree topology was evaluated under GTRGAMMA to yield stable likelihood values.

\section{Results and discussion}

The female specimens $(n=20)$ had a total length ranging between 0.54 and $0.57 \mathrm{~mm}$ (Fig. 1b). They possessed a strong and ventrally curved, sharply pointed rostrum (Fig. 1d). The caudal rami were nearly $1.2 \times$ longer than wide. The distal spines of the basipodid 2 (B2) of the mandible (Md) were thick, slightly curved, and blunt (Fig. 1c). At the maxillule (Mx1), the distal spine of the inner lobe (Li1) was longer than the other spines (Fig. 1f), and the endopod (End) carried only one seta. The outer margins of the exopod segments 1-3 (Exp1, Exp2, Exp3) of the swimming legs (P1-P4) have the following number of spines 1, 1, 3; 1, 1, 3; 1, 1, 3; 1, 1, 2 (Fig. 1e). The combination of a strong ventrally pointed rostrum and the same number of spines of the outer margins of the P1-P4 exopods is only known for five Oithona species $(O$. robusta, $O$. brevicornis, $O$. aruensis, $O$. wellershausi, and $O$. davisae; Ferrari and Orsi 1984). However, O. davisae has only one seta on the endopod of Mx1, while the other four species have three setae (Nishida 1985). Thus, we conclude that the specimens found in the List Tidal Basin equal Oithona davisae Ferrari and Orsi, 1984, which was confirmed by S. Nishida (personal communication).

Oithona davisae specimens can easily be differentiated from the other Oithona species occurring in the North Sea (Table 1): In O. plumifera and $O$. atlantica, the rostrum is pointed anteroventrally and as such is visible from a dorsal view. In $O$. similis, the rostrum is also pointed ventrally, but much smaller. $O$. nana does not have a rostrum. In all four species, the distal spines of the mandibles are pointed and not blunt as in $O$. davisae.

But not only the morphological characters revealed that the Oithona species found in the northern Wadden Sea was different from the other species known from the North Sea, the evidence can also be seen in the maximum likelihood tree of $28 \mathrm{~S}$ sequences. Interesting to note is also that three species from the northern Atlantic seemed to be closely related in $28 \mathrm{~S}$ and were divided from the Pacific species $O$. dissimilis, $O$. brevicornis from GenBank (accession numbers are included in Fig. 2), and $O$. davisae provided by this study. So far, no $O$. davisae sequences have been submitted to GenBank to compare our data with. But the 
Table 1 Comparison of characteristics among the Oithona species occurring in the North Sea and O. davisae

\begin{tabular}{|c|c|c|c|c|c|}
\hline Characters & $\begin{array}{l}\text { O. similis } \\
\text { Claus, } 1866\end{array}$ & $\begin{array}{l}\text { O. nana } \\
\text { Giesbrecht, } 1892\end{array}$ & $\begin{array}{l}\text { O. plumifera } \\
\text { Baird, } 1843\end{array}$ & $\begin{array}{l}\text { O. atlantica } \\
\text { Farran, } 1908\end{array}$ & $\begin{array}{l}\text { O. davisae } \\
\text { Ferrari and Orsi, } 1984\end{array}$ \\
\hline $\begin{array}{l}\text { Total length } \\
(\mathrm{mm})\end{array}$ & $0.68-0.96$ & $0.5-0.65$ & $1.18-1.28$ & $1.14-1.43$ & $0.54-0.62$ \\
\hline $\mathrm{P}: \mathrm{U}$ & $1.1-1.4$ & $1.0-1.2$ & $1.0-1.2$ & $1.1-1.3$ & 1.2 \\
\hline Rostrum & $\begin{array}{l}\text { Curved, short, } \\
\text { and pointed }\end{array}$ & No & $\begin{array}{l}\text { Not curved, pointed, } \\
\text { dorsally visible }\end{array}$ & $\begin{array}{l}\text { Not curved, pointed, } \\
\text { dorsally visible }\end{array}$ & $\begin{array}{l}\text { Curved, strong, and } \\
\text { ventrally pointed }\end{array}$ \\
\hline Caudal rami $\mathrm{L}: \mathrm{W}$ & $1.9-2.4$ & $2.1-2.7$ & $3.0-3.7$ & $3.1-3.8$ & 3.0 \\
\hline $\begin{array}{l}\text { Mx1 Li1 distal } \\
\text { most spine }\end{array}$ & Short & Short & Short & Short & Longer than other setae \\
\hline $\begin{array}{l}\text { Mx1 End no. of } \\
\text { setae }\end{array}$ & 1 min seta & 1 seta & 1 min seta or lacking & 1 long seta & 1 seta $^{a}$ \\
\hline $\begin{array}{l}\text { Md B2 distal } \\
\text { spines }\end{array}$ & 2 pointed spines & $\begin{array}{l}1 \text { long and } 1 \mathrm{~min} \\
\text { pointed spine }\end{array}$ & $\begin{array}{l}1 \text { longer and } 1 \text { shorter } \\
\text { pointed spine }\end{array}$ & $\begin{array}{l}1 \text { longer and } 1 \text { shorter } \\
\text { pointed spine }\end{array}$ & $\begin{array}{l}2 \text { thick blunt curved } \\
\text { spines }\end{array}$ \\
\hline \multicolumn{6}{|c|}{ Outer marginal spines (Exp1, Exp2, Exp3) } \\
\hline $\mathrm{P} 1$ & $1,1,2$ & $1,1,3$ & $1,1,2$ & $1,1,2$ & $1,1,3$ \\
\hline $\mathrm{P} 2$ & $1,0,1$ & $1,1,3$ & $1,0,2$ & $1,0,2$ & $1,1,3$ \\
\hline P3 & $1,0,1$ & $1,1,3$ & $1,0,1$ & $1,0,1$ & $1,1,3$ \\
\hline $\mathrm{P} 4$ & $0,0,1$ & $1,1,2$ & $0,0,1$ & $0,0,1$ & $1,1,2$ \\
\hline References & Nishida (1985) & Nishida (1985) & Nishida (1985) & Nishida (1985) & Ferrari and Orsi (1984) \\
\hline
\end{tabular}

${ }^{a}$ This sets this species apart from $O$. brevicornis, O. aruensis, and $O$. wellershausi who have 3 setae on the endopodid of the maxillule

sequences we submitted may help other researchers to determine the geographic origin of $O$. davisae in the Wadden Sea.

In the List Tidal Basin, O. davisae was first observed in October 2010 while conducting sampling for Oithona specimens. However, most of the specimens were used for genetic purposes and thus not available for morphological analysis. In June 2014, the remaining three female specimens were first identified as $O$. davisae. To investigate whether the occurrence of $O$. davisae in the North Sea had been only a single event in 2010, samples of the time series (2007-2012, August-September) in the List Tidal Basin were checked (Martens and Beusekom 2008) and a new non-quantitative sample was taken in August 2014 at the same station. This sample contained many copepodites, males and females with or without egg sacks. Next to Acartia sp., O. davisae was the most common zooplankton species in this sample. From the time series, only the presence or absence of Oithona species was noted. $O$. davisae was present in all of the samples inspected dating back to 2008. In 2007, it could not be found, and we did not have access to older samples. These findings provide evidence that $O$. davisae not only is present in the Wadden Sea since at least 2008, but that it has also successfully reproduced and settled. Furthermore, in all samples we looked at, neither $O$. similis nor $O$. nana was found.

To our knowledge, the cyclopoid copepod $O$. davisae is the fifth non-indigenous planktonic copepod species found in the coastal waters of the North Sea. However, the other four species were all calanoid copepods. In the Atlantic and its adjacent seas, $O$. davisae has only been reported from the western Mediterranean and the Black Sea (Saiz et al. 2003; Temnykh and Nishida 2012). Originally, O. davisae is considered to be endemic to the temperate coastal waters of East Asia (review in Temnykh and Nishida 2012). However, it was first described from the St. Joaquin estuary in northern California (Ferrari and Orsi 1984). The authors speculated due to its close morphological relationship with the Indo-Pacific species $O$. wellershausi and $O$. aruensis that this species might have been introduced to the estuary by ballast water from ships coming from Asian harbours. Later, it has been observed in ballast water tanks arriving mainly from Japan in the San Francisco Bay area (e.g. Choi et al. 2005). All other records in the Pacific and the Atlantic Ocean are considered to be evidence of new introductions probably transferred with ballast water tanks. Thus, we suggest that $O$. davisae was most likely transported via ballast water tanks into the North Sea. This is also congruent with the findings for the other four introduced planktonic copepod species (Brylinski 1981; Seuront 2005; Brylinski et al. 2012). However, all other four species were first found in coastal waters of the southwestern North Sea near big harbours, while $O$. davisae was found in the northeastern Wadden Sea. The nearest harbour would be Hamburg. Thus, O. davisae might have been arrived near the harbour, established itself there, and then extended its 
distribution further to the north. However, to our knowledge, the station at the List Tidal Basin is the only regularly sampled zooplankton station in the eastern Wadden Sea. To investigate how far $O$. davisae has spread within the Wadden Sea, further sampling is needed at different locations.

The Wadden Sea may be a favourable habitat for $O$. davisae, a unique coastal environment subjected to a pronounced seasonality in temperature, phytoplankton, and zooplankton (e.g. Martens and Beusekom 2008), which is also true for its original habitat, the coastal waters of southwestern Japan (Nishida 1985; Uye and Sano 1998). There temperatures range between 8.9 and $28.2{ }^{\circ} \mathrm{C}$ (Uye and Sano 1998), which is generally higher than in the studied Wadden Sea station (between -1.8 and more than $20{ }^{\circ} \mathrm{C}$ (Martens and Beusekom 2008)). The warming of the Wadden Sea (Martens and Beusekom 2008) may have provided the right environment for $O$. davisae to settle. Reise and van Beusekom (2008) revealed that global warming is an important factor for species invasions in the Wadden Sea, since most of the introduced species originate from warmer regions than the North Sea.

Martens and Beusekom (2008) published results from the time series in the List Tidal Basin between 1984 and 2004 and recorded only $O$. similis, which occurred in low numbers throughout the year until 1996 when suddenly the abundances increased in autumn and have stayed high ever since. As stated above, we did not observe any $O$. similis specimens in the time-series autumn samples between 2007 and 2012. In the eutrophic embayments of southwestern Japan, the natural habitat, $O$. davisae is often the most abundant copepod (review in Uye and Sano 1998), even more abundant than $O$. similis, especially in the inner part of inlets. In the Black Sea, especially at Sevastopol Bay, O. davisae has become one of the most common copepod species with abundance peaks in autumn since its first appearance in 2001 (Altukhov et al. 2014). Thus, within less than 15 years, this species seems to be able to establish itself successfully in a new environment. So the question arises whether $O$. davisae has replaced $O$. similis in the List Tidal basin. A comparison between the List Tidal Basin and a reference station outside of the bight may give further insight in this matter.

Most probably, O. davisae is now a permanent immigrant in the northern Wadden Sea, documented by its presence in 2008-2012 and 2014. It also seems to be able to reproduce as copepodite stages; males and females with egg sacks were found in 2014. However, it remains unknown when $O$. davisae was introduced to the North Sea, from where, and how. Some answers to these questions may be given by revisiting the older samples of the zooplankton time series in the List Tidal Basin, by genetic population studies, and investigations of ballast water tanks arriving to the harbours connected to the North Sea. The most plausible explanation how this species arrived in the Wadden Sea would be the introduction by ballast water from ships travelling through the North Sea. It also remains unknown how far $O$. davisae has spread in the Wadden Sea. Thus, it might be worth to investigate the extent of the success of $O$. davisae in coastal North Sea waters.

Acknowledgments The authors would like to acknowledge the help of Andrea Eschbach and Christoph Held. Harald und Ragnhild Asmus kindly provided access to samples from the time series stored at the Wattenmeerstation Sylt. We are also grateful to Shuhei Nishida who kindly confirmed the identification of $O$. davisae. A.C. was supported by the Deutsche Forschungsgemeinschaft (DFG) in the framework of the priority programme "Antarctic Research with comparative investigations in Arctic ice areas" (CO706/2-1).

\section{References}

Altukhov DA, Gubanova AD, Mukhanov VS (2014) New invasive copepod Oithona davisae Ferrari and Orsi, 1984: seasonal dynamics in Sevastopol Bay and expansion along the Black Sea coasts. Mar Ecol 35:28-34

Brylinski JM (1981) Report on the presence of Acartia tonsa Dana (Copepoda) in the harbour of Dunkirk (France) and its geographical distribution in Europe. J Plankton Res 3:255-260

Brylinski J-M, Antajan E, Raud T, Vincent D (2012) First record of the Asian copepod Pseudodiaptomus marinus Sato, 1913 (Copepoda: Calanoida: Pseudodiaptomidae) in the southern bight of the North Sea along the coast of France. Aquat Invasions 7:577-584

Cepeda GD, Blanco-Bercial L, Bucklin A, Berón CM, Viñas MD (2012) Molecular systematic of three species of Oithona (Copepoda, Cyclopoida) from the Atlantic Ocean: comparative analysis using 28S rDNA (D Steinke, Ed). PLoS One 7:e35861. doi:10.1371/journal.pone.0035861

Choi KH, Kimmerer W, Smith G, Ruiz GM, Lion K (2005) Postexchange zooplankton in ballast water of ships entering the San Francisco Estuary. J Plankton Res 27:707-714

Ferrari FD, Orsi J (1984) Oithona davisae, new species, and Limnoithona sinensis (Burckhardt, 1912)(Copepoda: Oithonidae) from the Sacramento-San Joaquin Estuary, California. J Crustacean Biol 4:106-126

Folmer O, Black M, Hoeh W, Lutz R, Vrijenhoek R (1994) DNA primers for amplification of mitochondrial cytochrome c oxidase subunit I from diverse metazoan invertebrates. Mol Mar Biol Biotechnol 3:294-299

Fransz HG (1983) Zooplankton species of the Wadden Sea. In: Wolf WJ (ed) Marine zoology, ecology of the Wadden Sea 4. Invertebrata. Balkema, Rotterdam, pp 12-23

Fransz HG, Colebrook JM, Gamble JC, Krause M (1991) The zooplankton of the North Sea. N J Sea Res 28:1-52

Gollasch S, Haydar D, Minchin D, Wolff WJ, Reise K (2009) Introduced aquatic species of the North Sea coasts and adjacent brackish waters. In: Rilov G, Crooks AJ (eds) Biological invasions in marine ecosystems. Ecol Stud 204:507-528

Jha U, Jetter A, Lindley JA, Postel L, Wootton M (2013) Extension of distribution of Pseudodiaptomus marinus, an introduced copepod, in the North Sea. Mar Biodivers Rec 6:e53. doi:10.1017/ S1755267213000286

Katoh K, Standley DM (2013) MAFFT multiple sequence alignment software version 7: improvements in performance and usability. Mol Biol Evol 30:772-780 
Martens P (1980) Beiträge zum Mesozooplankton des Nordsylter Wattenmeers. Helgol Meeresunters 34:41-53

Martens P, Beusekom JEE (2008) Zooplankton response to a warmer northern Wadden Sea. Helgol Mar Res 62:67-75

Nishida S (1985) Taxonomy and distribution of the family Oithonidae (Copepoda, Cyclopoida) in the Pacific and Indian Oceans. Bull Ocean Res Inst Univ Tokyo 20:1-167

Ortman BD (2008) DNA barcoding the medusozoa and ctenophora. Ph.D. Dissertation, University of Connecticut, Storrs, CT

Razouls C, de Bovée F, Kouwenberg J, Desreumaux N (2005-2014) Diversity and geographic distribution of marine planktonic copepods. http://copepodes.obs-banyuls.fr/en. Accessed 14 Oct 2014

Reise K, van Beusekom JEE (2008) Interactive effects of global and regional change on a coastal ecosystem. Helgol Mar Res 62:85-91

Saiz E, Calbet A, Broglio E (2003) Effects of small-scale turbulence on copepods: the case of Oithona davisae. Limnol Oceanogr 48:1304-1311
Seuront L (2005) First record of the calanoid copepod Acartia omorii (Copepoda: Calanoida: Acartiidae) in the southern bight of the North Sea. J Plankton Res 27:1301-1306

Stamatakis A (2006) RAxML-VI-HPC: maximum likelihood-based phylogenetic analyses with thousands of taxa and mixed models. Bioinformatics 22:2688-2690

Temnykh A, Nishida S (2012) New record of the planktonic copepod Oithona davisae Ferrari and Orsi in the Black Sea with notes on the identity of "Oithona brevicornis". Aquat Invasions 7:425-431

Uye S-I, Sano K (1998) Seasonal variations in biomass, growth rate and production rate of the small cyclopoid copepod Oithona davisae in a temperate eutrophic inlet. Mar Ecol Progr Ser 163:37-44

Wend-Heckmann B (2013) Oithona similis (Copepoda: Cyclopoida)—a cosmopolitan species? Universität Bremen, PhD thesis, $1-174$ 